\title{
Solidarity in spaces of 'care and custody': The hospitality politics of immigration detention visiting
}

\section{Introduction}

In recent years, criminological interest in state practices that criminalise, police, detain and deport migrants has become well established (Aas and Bosworth, 2013; Coutin, 2005). Immigration detention has been identified as a cornerstone of a distinct "crimmigration" system (Bowling and Westenra, 2018; Pakes and Holt, 2016; Stumpf, 2006). Detention runs according to its own logics of estrangement and disavowal that distinguish it from criminal imprisonment (Bosworth, 2013; Silverman and Massa, 2012) producing specific racialized identities and relationalities (Bosworth, 2012; Turnbull, 2017). Movements that contest crimmigration powers also invoke distinctive normative postures; they frequently mobilize a discourse of hospitality to demand that the state and its citizenry respect the rights of its migrant 'guests'.

This article makes two interventions. Firstly, it addresses debates about the role of hospitality in critical responses to the UK's border regime. Focusing on the activities of detention visiting groups, it seeks to understand the ways the concept of hospitality can be deployed both to critique and think alongside anti-detention activists in their attempts to perform an emancipatory politics in and against carceral spaces of border enforcement. Secondly, it contributes to criminological understandings of the role of private and voluntary actors in the delivery of services and care in custody (Bales and Mears, 2008; Moran, 2013; Tomczak, 2014) and in the logics and strategies of movements that resist contemporary carceral politics (Lamble, 2013; Scott, 2009). The article examines the complicity of ostensibly benevolent actors in spaces of migrant incarceration and identifies strategies of subversion developed to navigate these complicities. The resulting discussion has implications for organised contestation over migration policies as well as scholarship on the politics of care and activism in response to state violence.

The concerns of anti-border politics raise questions of hospitality in two connected ways. The first relates to the language, presentation and demands of pro-migration campaigning that frequently deploys discourses of hospitality to press for increased 
refugee resettlement programmes and support for refugees and people seeking asylum in the UK. The 'City of Sanctuary' movement (see: Darling, 2010), in its effort to foster a positive local response to migration, sought to change attitudes towards refugees and to create welcoming support networks. Similarly, the Refugees Welcome movement ${ }^{1}$ has popularised humanitarian responses to the so-called migrant crisis by drawing on a mythology of British hospitality (Gibson, 2006), mobilising sentiments of welcome for those particularly in need, pushing for the British government and people to transform from inhospitable to hospitable hosts. In contesting policies and discourses that explicitly foster a 'hostile environment' for people with insecure immigration status that keep migrants in the position of 'eternal guests' on 'eternal probation' (Kanstroom, 2007), these projects engage with a line of cosmopolitan political thought about the state's legal and moral obligations toward immigrants (Baker, 2010; Brown, 2010; Friese, 2010).

The second concerns the embodied, social practices that migrant solidarity groups carry out to support migrants. Activists working with people subject to border control confront a constitutive tension within their work. While their activities are motivated by the pursuit of equality, the practice of anti-border work often sustains the very demarcations of difference (Friese, 2010) and the unequal distributions of agency, expertise and social capital that anti-border projects seek to challenge (Fadaee, 2015; Millner, 2011). Work on prefigurative politics has highlighted the ways activist groups seek to reimagine processes of democratic organising that attempt to address internal power dynamics (Maeckelbergh, 2011). However, horizontal interaction with people outside an organising group who are subject to direct or indirect control by border enforcement agencies is challenging. Critical interpretations of humanitarian and activist practices have deployed the concept of hospitality to investigate the conflicted and ambivalent nature of this work (Darling, 2009, 2010; Millner, 2011; Rozakou, 2012).

In these practices of campaigning and support, citizen-activists are positioned as hosts while migrants are positioned as guests. In doing so, these discourses naturalise dominant representations of who has ties to a place and who does not. The casting of the migrant as the guest of the 'host'-nation is, as Rosello (2001) suggests, a 'metaphor that forgot it was a metaphor'; it naturalises the citizen's status of belonging and

\footnotetext{
${ }^{1}$ For example: 'Britain has always been ready and willing to welcome refugees in times of crisis' http://www.refugees-welcome.org.uk/ accessed $1^{\text {st }}$ April 2017
} 
dominance in a space while emphasising the supposed mobility and illegitimacy of the migrant other.

Hospitality, then, is not a straightforwardly positive response to difference (Candea and Da Col, 2012; see: Lynch et al., 2011). Critical approaches, often drawing upon Derrida's $(1997,2005 ; 2000)$ work, have articulated the ways that hospitality involves the contradictory entwinement of openness and welcome with closure and hostility. For some writers (Darling, 2014; Millner, 2011) the limitations of hospitality politics mean that it should be rejected in favour of alternative visions of progressive, solidaristic practices of anti-border work. However, this article argues that, with important modifications, Derrida's concept of hospitality helps to understand the ways that detention visitors are experimenting with the roles of host and guest. Detention visiting both reasserts the dominant forms of host-guest relations but also reimagines the anti-detention volunteer role from a hosting subject to a visiting subject. I argue that the co-presence of these divergent ways of offering hospitality allow visitors to navigate and live with the complicities and unequal relationships afflicting solidarity with migrants in carceral-border spaces.

The article forms part of a wider project that explores the dynamics and dilemmas of anti-detention activism with a focus on activisms that seek collaborative relationships with those resisting detention from within. The empirical basis for this article consists of: three years' participation in detention visiting, during which I visited ten people in four detention centres; interviews with fourteen visitors from three visiting groups; and three interviews with people who had experience of being visited while in detention. My positionality as someone who has not been detained and has not been targeted by immigration detention, and the weighting of interviews on activist visitors rather than those in detention, means that the article is primarily focused on the political thinking ongoing within detention activism rather than on attempting to provide a representative account of detention visiting that includes accounting for the ways those in detention experience visits. These interviews were made possible by agreement with visiting groups I worked with, through my own networks. I have anonymised interviewees using pseudonyms to protect their confidentiality and, since it is not my intention to compare the visiting practices of different groups, I have not identified which group they visit with. My case studies included groups that viewed detention visiting as part of an explicitly anti-racist praxis and included a greater proportion of visitors of colour than would be representative of visitors nationally. For this reason, the article focuses on how visitors navigate their relative freedom and inexperience of border control as the key markers of visitor-privilege rather than 
whiteness, even though whiteness is often a pertinent and under-discussed aspect of the experience of detention visiting.

I begin the article by introducing the Derridean conceptual approach to hospitality. Then, after introducing the practice of detention visiting, I examine the divergent logics of 'hosting' and 'visiting' operating in detention visiting. I argue that, with modifications, critical hospitality studies is a useful frame through which to understand the dynamics of visiting and that engaging in migrant detention as a visitor may be a more fruitful conceptual frame for abolitionist solidarity than the figure of the benevolent host that often features in liberal interventions on border control.

\section{Derridean approaches to Hospitality}

Derrida's writing on hospitality aimed to reshape state responses to migrants and refugees by drawing on and reworking European traditions of hospitality (Carlson, 2009). His work is concerned with facilitating critical engagements with state decision making. Derrida's uses his methodological deconstruction to identify the ways the state in Western political thought develops conditional laws of hospitality that structure state recognition and response to non-citizen migrants in its territory (Westmoreland, 2008). For these conditional laws to escape being purely oppressive, hostile and defensive they need to be driven by a commitment toward an unconditional hospitality, the perpetual demand for an absolute opening to the other ${ }^{2}$. Derrida objects, for example, to Kant's (1795) reduction of hospitality to a matter of rule-making. Instead, he advocates for a non-reductive ethics of hospitality that requires the responsibility of decision makers not to be subsumed by the application of rules (Derrida, 1997). For both structural and practical reasons, unconditional hospitality is impossible to fully achieve and institutionalise. ${ }^{3}$ Yet, Derrida demands that the state approach unconditional hospitality through the drawing up and application of laws and pursuing their continual deconstruction or renewal through

\footnotetext{
${ }^{2}$ Hosting unconditionally then is the ability to fully displace oneself as host and to relinquish control to an unexpected visitor (Derrida and Anidjar, 2002: 361).

${ }^{3}$ The impossibility of unconditional hospitality results from the fact that the conditions of possibility for unconditional hospitality are also its conditions of impossibility. The offer of hospitality, immediately differentiates the host from the guest, positioning the former as the one who belongs and who is therefore the agentic and empowered actor.
} 
supplementary overreaching decision that asymptotically approaches the unconditional (Darling, 2009; Derrida, 1989).

Derrida's focus on the host-state decision provokes two critiques by those attempting to articulate progressive hospitality politics. Firstly, the focus on state hospitality reveals the limits of Derrida's political horizons. Hospitality, in Derrida's vision, appears as a form of 'civil disobedience', a project which seeks to break the existing laws through faithfulness to the project of law (Rocha Gómez, 2014). For some, therefore, Derrida's position is a rather more conservative disposition than may first be apparent (Barnett, 2005); it affirms the need for legally enforced borders, expulsion and other limitations of hospitality, while at the same time suggesting that one should always be open to the need to exceed these rules ${ }^{4}$.

Secondly, it is unclear how the abstract, 'cerebral' politics (Reynolds, 2002: 463) of state decision-making relates to material practices of hospitality. Derrida's willingness to draw analogies between the hospitality of the psyche, home, the nation and the state has been criticised. Without such an account of how the state and local hospitality interact, Candea (2012) accuses Derrida's work of 'scale-free abstraction' where national and community relations translate without resistance to local and interpersonal contexts. While it may be the case that 'localised acts of hospitality, on a bus or at home, speak to national contests over spatial sovereignty' (Candea and Da Col, 2012: 14), they might operate in subversion or in parallel with national scales. An engagement with diverse material practices of hospitality exposes the ways that nonstate actors are enrolled into practices of hosting that are obscured by Derrida's focus on the sovereign mastery over territory (Bulley, 2015).

Despite these concerns, there is value in using Derrida's work on hospitality to think about spaces such as the detention visiting room. Derrida's approach motivates a willingness to explore the possibility of critical political practices that engage with, but do not in themselves attempt to challenge, practices of state violence and exclusion. In such spaces, while the practice of hospitality may be more fluid and negotiated than is conveyed by Derrida's notion of conditional hospitality, unconditional hospitality is still beyond the possibility of the moment. Yet, the inability to establish relations of

\footnotetext{
${ }^{4}$ Derrida is, of course, aware of the dangers of focusing unduly on the limits of hospitality. As Derrida writes 'immigration must, it is said, be 'controlled'... [unconditional hospitality] is always forgotten, by definition in the name of xenophobia; but can also be forgotten in the name of a certain interpretation of 'pragmatism' and 'realism"' (Derrida, 2005: 7).
} 
unconditional hospitality does not exhaust the political stakes in practices of engagement. Instead, progressive practices of pro-migration politics must be found in occupying the aporetic space between conditional and unconditional hospitality, and the intertwinement of hostility and hospitality.

Derrida's writing renders hospitality as a domain of ethical and political praxis that may be inhabited in diverse ways ${ }^{5}$. These practices work to determine relationships across difference (between self and other, host and guest) and in the process, also constructs and polices those differences. While acts of hospitality are concerned with opening up to outsiders and enabling border crossings, they are simultaneously concerned with articulating those borders, defining otherness and establishing rules of acceptable engagement. The assignment of host and guest roles often involves assumptions about who belongs and what they own (Hamington, 2010), their legal status (Stronks, 2012), whether they are new to a place and how mobile they are (Humbracht, 2015). Discourses of hospitality therefore frequently participate in gendered, classed and racialized patterns of difference (Gardey, 2016).

Furthermore, Derrida's writing draws attention to the ways that demarcations of host and guest roles are intimately bound up with the distributions of power that they sustain. Derrida draws upon the etymological analysis in Benveniste's 1969 work to make this point (Benveniste and Lallot, 1973). Benvensiste notes that the word hospitality has roots in the Latin hostis (foreigner, enemy) and pet (power, selfassertion) (Candea and Da Col, 2012). Even in the most hospitable circumstances, hospitality always involves both hospitality and hostility. The intertwinement of hospitality and hostility is brought out in the Derridean neologism, hostipitality. As will become apparent below, this concept is useful in navigating spaces, like detention, that are sustained by both overtly hospitable and overtly hostile practices.

Hospitality draws attention to the ways host-guest roles are enabled by the powerimbued materiality of space that enables some to more easily fulfil the requirements of a host. As Derrida writes, echoing the common gendered assumptions of hospitality, 'He [the host] receives the hospitality that he offers in his own home, he receives it from his own home - which, in the end, does not belong to him. The hôte as host is a

\footnotetext{
${ }^{5}$ Following Judith Still's (2010) account, Derrida's work is not intended to demarcate a particular ethics or politics of hospitality. Derrida writes, for example, that 'hospitality is culture itself and not simply one ethic amongst others' (Derrida, 2001: 16). Elsewhere, Derrida writes that '[hospitality] is ethicity itself, the whole and the principle of ethics' (Derrida, 1997: 50).
} 
guest...The one who welcomes is first welcomed in his own home' (Derrida, 1997: 41). A defining feature for Bulley (c.f. Baker, 2010) is that 'hospitality requires spatial boundaries that it simultaneously displaces through their crossing' (Bulley, 2015). For Bulley, it is this spatiality that separates hospitality from other instances of taking responsibility for the other: hospitality occurs when spatial networks distribute power to allow one to perform as host and constructs the other as a mobile visitor that is temporally moored in the space of the host (Lynch et al., 2011).

For hospitality studies to be useful for understanding the politics of detention visiting, two conceptual shifts need to be made. Firstly, the assumption that demarcations of belonging in a place determines who can take on hospitality roles has led to theorists to view hosts and guests as automatic products of social conditions rather than as objects of strategy. Those interested in thinking through hospitality beyond Derrida's vision have identified situations that do not conform to the dominant migrant-guest, state-host dynamic (Humbracht, 2015; Rozakou, 2012) as well as situations where guests over time become hosts (Bulley, 2015). However, few have explored spaces where there is ambiguity, strategy and play with hospitality roles. Drawing on Hamington's (2010) conception of hospitality as performativity, I argue that visitors strategically oscillate between hosting and visiting roles in order to navigate the power-laden space of the detention visiting room.

The second shift required for hospitality studies to be relevant to detention visiting is to reject the preoccupation with hosting as a means of performing hospitality. The Levinasian influence in hospitality studies has encouraged a 'self-flattering even if guilty, focus on the host' (Still, 2010: 9) that devalues the visitor as an ethical and political subject capable of acting responsibly. Yet, as I shall argue in the pages that follow, detention visiting raises the possibilities of a hospitality politics in which the host is not the primary subject.

\section{Visiting people in detention}

There is limited academic work that interrogates volunteer visiting to people in custody. Visiting immigration detention is briefly discussed by Bosworth (2014) who finds that, while some detainees find visiting a lifeline, others are concerned by the lack of legal help offered. The prison visiting scholarship focuses on measuring and conceptualising the effect of regular visitation on the behaviour and recidivism rate of people in prison. With quantitative methodologies, it has been ascertained that visiting correlates with lower rates of recidivism (Bales and Mears, 2008; Cochran and Mears, 
2013; Duwe and Clark, 2013) and 'improves' prisoner behaviour (Cochran, 2012). These numbers appear to confirm long running expectations in the prison visiting literature that visiting aids the pacifying effects of the prison, turning those detained into docile bodies who will 'do their time' (Moran, 2015). This work, therefore, does not investigate visiting as a site of political activity.

Visiting people in detention in the UK is organised by the 20 detention visiting groups located around the country that collectively support around 650 volunteer visitors ${ }^{6}$. Because of their sporadic decentralised emergence, they differ greatly in terms of political ethos and motivation. They include rights focused, religious and anti-border groups. While groups and individuals vary in the styles of visiting, they each attempt to combine three interweaving projects: case-work service provision, political friendship and resistance.

Casework support: Visiting groups are often engaged in non-legal casework activity that support people through the institutional, legal and practical barriers to release. This includes referrals to legal and medical NGOs, finding, liaising with and chasing up lawyers, and evidence gathering.

Political friendship: Visitors offer friendship in a space designed to separate people from community belonging. Visitors often form close affective attachments to particular people in detention fostered over a number of weeks and months. For Adam, what was special about visiting was the opportunity to 'create mutual obligations and commitment to someone in particular' rather than performing a commitment to an abstract political problem.

Resistance to detention: Participants conceptualised resistance to detention in a variety of ways. For Laura, visiting people in detention attempted to counter the imposed estrangement of those who were detained by 'opting to go into a place that everyone wants to get out of and that, in my understanding of how the system works, the government ... doesn't want you to go into and doesn't want to you talk about'. Visiting groups also engage to varying degrees in campaigning for detention reform or abolition.

Visitor groups typically employ a small group of caseworkers or coordinators, who work in offices near the centres, recruit and train visitors and act as a contact point for

${ }^{6}$ http://www.aviddetention.org.uk/what-we-do/supporting-our-members [accessed 20/5/2018] 
people in detention. These employed staff keep in regular contact with people visited to monitor visits. They will also offer practical assistance to clients and monitor changes in detention centre conditions and breaches of detention centre rules. When a group receives a referral, they pass on the detainee's contact details and some background information to a visitor who then contacts the person in detention to arrange a visit.

On arrival at the detention centres, visitors check in with detention centre staff. Fingerprints and photographs are taken in exchange for a wristband and visitor lanyard that must be worn throughout the visit. Visitors are searched as they pass through security; the guards are likely to look in the visitor's shoes, maybe in their mouths. The visitor enters a larger room full of low tables and waiting room chairs. There is a desk behind which a guard or two will sit monitoring CCTV screens. The visitor is required to give their fingerprints again. The visitor will be told to sit and wait at their allocated table for the person detained to be found and brought to the visiting room. Out of a separate door on the other side of the room, the detainee will be brought in, ready to be welcomed to the table by the visitor.

\section{Detention volunteers as hosts}

Despite their guest status in the centre, the visitors' relationships with people in detention often replicate dominant patterns of citizen-host and migrant-guest hospitality. This hosting role is, in some cases, taken on explicitly through their attempts to create a hospitable environment that counters the inhospitable actions of the detention system. As one visitor, Jane, said about her motivations to volunteer: 'I think that a lot of people in Brook House feel that everyone in the UK hates them, and that they aren't welcome full stop'. Others described their attempts to be kind, smiling, helpful as attempts to be 'welcoming' and as part of the struggle to make the country a more hospitable place.

More often, hosting is an implicit aspect of the visitor's role. Visitors frequently adopt a pastoral position an offer care to the people detained. Those I interviewed emphasised the emotional support they offered, which consisted in creating time and space outside of the normal routines of incarcerated life. The people in detention I spoke to emphasised their exposure to traumatic events such as suicide attempts and enforced removals. For them, visits were vital to their struggle simply to survive. Visits broke up their routine and reduced the pressure of detention. The value of visiting, in 
this view, is reduced to a service given to detainees. As Ed put it in an interview, visiting injects a 'little humanity' into the banal, bureaucratic and inhuman processing of people's deportation.

Becoming part of the detention landscape, visiting groups often use posters and dropin workshops within the institutions to attract detainees to use their service and to attempt to reach the most vulnerable people. To secure this access, visitor groups attempt to foster working relationships with the security company staff who run the centres. While these strategies may enable visiting groups to reach more people and access stakeholder meetings with detention centre staff, they also require them to submit to the hospitality and, therefore, the control of the detention centre and the company that runs them. In some cases, the security companies insist that visitor groups concern themselves exclusively with emotional support and prevent them from conducting case work that attempts to get people out of detention (Hannah, Interview). Visiting groups have been banned, for example, from having drop-in sessions, for writing critical social media posts, and for making complaints against staff.

In parallel with Derridean critiques of rule-based hospitality (See Baker, 2010), detention visiting groups often prescribe particular roles for their visitors to adopt. At a training session for new visitors, Brian, who was facilitating the session, delineated a division of labour between coordinators and visitors stating that "Your role is emotional support, and we do the practical work." The delimitation of responsibility and role of visitors is often combined with a visitor agreement that prohibit visitors from engaging in more political engagements with detention. Visitors are often prohibited from attending protests, from speaking to the media, sometimes from sharing their own telephone number with people in detention and from acting as sureties for bail. Brian explained the reasons for the fixed boundaries and roles in the follow way:

The idea of having boundaries is trying to make sure that the work is sustainable. There is an unlimited amount of bad stuff in the world. It's important that you take perspective. When people take it all on themselves, it burns them out. It's always worth bearing in mind, that by visiting you're doing a big thing. You are taking a responsibility and that is enough.

This quotation indicates the stake visitors have in preserving their place over time but also suggests that this is achieved in part by pre-established boundaries that enable sustainable visiting. While it is unclear how the rules and boundaries shape the visitor 
role and experience, these regulatory activities imagine the role of visitor as fixed before visiting begins rather than the nature of the relationship being explicitly an object of negotiation between visitors and the people they visit. However, the rules imposed do not completely contain the interactions that occur and the relationships that are fostered through it. Often visiting occupies the grey areas, pushing beyond the limitations imposed by group rules.

Case-work support is often pursued by both group coordinators and visitors themselves. Volunteers perform hospitality through information-giving, mediating between migrant-guests and the environment that they are held within, helping them to understand the place they visit and interpreting the environment (Reisinger and Steiner, 2006). Detention visitors and coordinators draw on their training, handbooks and experience to help navigate the complexities of detention and the inadequate information given to detainees (Rowlands, 2018). This is done through 'signposting' to relevant NGO services, legal support networks and complaints procedures. Though visitors are criminally prohibited from giving legal advice, they frequently help people with their immigration cases by making sense of documents, finding or chasing up lawyers, and even gathering evidence.

In summary, detention visitors position themselves as part of the hosting project offering bounded, pre-determined services to people that provide practical help and emotional support. They embed themselves as part of the institutional make-up of detention. Detention volunteering, therefore, reflects the Derridean characterisation of hospitality in which there is a demarcation of hosts and guests, hosts assert belonging in the space (Dikeç, 2002) and hosts determine the purpose and boundaries which underpin the relationship.

\section{Hosting in a space of hostipitality}

Approaching the work of detention volunteers as a hosting project in which hosts offer particular pre-defined services to those in detention positions those in detention as a distinct population with a set of needs that visiting groups understand and can work to fulfil. While this approach undoubtedly has some positive effects it also generates disparity in the amount each person knows about each other. For example, Helen, a visiting coordinator, said:

What I find frustrating is that there is a power imbalance but the person you are visiting has a whole wealth of experience. But because of the 
situation you meet them in, yours is seen as more professional, more valued. That relationship creates a feeling which I don't think is useful... The power imbalance is so easy to happen and so difficult to overcome, to get to a point that they are an equal in a difficult situation.

As Helen suggests here, there is often an assumption that visitors are more knowledgeable about how to navigate the immigration system, even though, as is often the case, people in detention have been living in the UK for significant periods of time or have had long experience of the UK border infrastructure. Centring the knowledge required to perform casework also can lead to the infusion of legalistic language and categories into the ways in which visitors think and respond to the person they visit. As Rozakou (2012) notes, the structuring of aid through legal categories of asylum seeker or foreign national offender has effects on who is considered worthy of being hosted. These worries are shared by Laura, who said that when visiting she was conscious to:

Avoid becoming someone who is assessing the story is credible and what bits are true and what bits are false. I think that's what's different about a more abolitionist stance to visiting. Someone's reasons for being in detention are not that important at all. And that's needed to move away from the stratifications of migrants - stepping away from all these narratives that place certain people's incarceration as more horrific than another's.

In the bounded care roles visitors adopt, they worry that visiting can replicate the dynamics of humanitarianism. For Mezzadra, the hospitality of humanitarianism promotes 'paternalistic logics' in which migrants are the objects of care 'denying them a chance to become subjects' (Mezzadra, 2004). A politics of hosting can result in a political imaginary that places the stable subjects of host and guest against each other; one with the power to choose the terms on which the other is accepted and the other constituted by their relationship to the host. This resonates with Fassin's critique of humanitarian politics as an 'act of assistance through which individuals identified as victims are established. They are those for whom the gift cannot imply a counter-gift, since it is assumed that they can only receive. They are the indebted of the world.' (Fassin, 2007: 512). The hospitality of humanitarianism therefore risks painting the visitor as the object of an agentic, benevolent host yet blinds us to the possibilities of prefiguring a more dynamic, more equal political dynamic in the process of resisting detention. 
As well as potentially problematic relationships with people in detention, a logic of hosting encourages detention visiting groups to take on contentious relationships with the detention centres themselves. The centrality of the instrumental logic of care in detention visiting corresponds to an imaginary of the detention centre as a hostile institution that creates the abject condition of people in detention. People in detention are frequently cast as people in desperate need, as those who are needlessly excluded and reduced to their deportability and who's only humanising characteristic is their vulnerability to the violence of the state's deportation and detention. The care work that NGO and charity workers engage in presents itself as confronting the exclusionary logics of detention rather than being complicit in it.

However, some visitors question the distinction between the care work that is performed by NGOs and charities in detention and the exclusionary and violent practices of the Home Office and security companies. For example, Laura said that:

One of the things visiting does is perpetuate the situation by propping up people who are in that place who might like act otherwise if there wasn't someone regularly visiting them and being regularly supportive. It walks the line of charity.

This view draws attention to ways that the centres are sustained by the numerous NGOs, charities and companies that offer many key services including healthcare, legal advice lines, art and music activities, the voluntary returns programs and, in the case of Barnado's, for a time at least, the actual management of one of the centres (Tyler et al., 2014). The dual institutional presence of NGOs and security services has been a noted strategy across border control and encampment policies in recent times (Andersson, 2014; Fassin, 2012). The presence of care as a key sustaining logic of border infrastructure (Gill, 2016) and its role in securing the legitimacy of state practices of exclusion needs to be confronted both by academic critics of border regimes and by the NGOs and activists working to create more egalitarian worlds. In this view, the detention centre is understood, less as a space of exclusion and hostility that can be countered by hospitable interventions but, rather, one in which the logics of hostility and hospitality are intertwined. If detention is a space of hostipitality, 
sustained by care as well as custody ${ }^{7}$, then, instead of countering the logic of these institutions, hospitable interventions facilitate their exclusionary effects.

\section{Detention volunteers as visitors}

In this final section, I articulate an alternative mode of hospitality adopted by detention volunteers by highlighting the ways that visitors practise hospitality as 'visitors' rather than as 'hosts'. In this approach, detention visitors attempt to form relationships beyond the client-advocate dynamic. This approach draws influence from Hamington's notion of performative hospitality that opens possibilities for subversive forms of hospitality in which feminist hosts refrain from 'recreating acts that constitute identity' and instead 'attempt to foster the atmosphere for lateral exchanges' (2010: 25). Visiting, I argue, involves holding a less firm grip on the instrumental rationality of visiting-as-support and exploring the possibilities of forming relationships with those in detention on terms that are established through a practice of conversation. This more open-ended form of creating relationships, I argue, is a distinctive mode from the hosting-ethic described in previous sections. It is an attempt both to assert a more unsettled and ambivalent relationship with the centre and to establish more responsive and transformative relationships with those people who are visited.

Since visitors, in any situation, always leave (Dikeç, 2002), visiting is not usually associated with taking responsibility in the ways that hosting is. However, this section challenges this proposition by understand visiting as a means of engaging in carceral spaces while attending to one's own positionality and relative inexperience and navigating the potential for complicity and co-option. Volunteers perform hospitality as a visitor in three ways. Firstly, visitors often try to distance themselves from the centre instead of becoming settled features of detention. As Lydia explained,

When I'm in the visiting hall, I'm very actively trying to separate myself from it by portraying to the person I'm supporting that I'm very separate myself from the centre and that I don't have nice interactions with the guards and don't have any respect for the rules really.

Visitors also performed their distance with the centre management through noncompliance with the questioning detention centre staff sometimes subject visitors to.

\footnotetext{
${ }^{7}$ It is worth noting that the subsidiary of Mitie that runs Harmondsworth and Colnbrook detention centres is called 'Care and Custody'.
} 
For example, they avoid saying which visitor group they are from, when asked, or that they are from a visiting group at all. These performances position the visitor and visiting group as an intervention in the space of the detention centre, rather than a feature of it. Visitors attempt to develop relations of accountability to the people they visit rather than to the detention centre's management in the ways described above. At an institutional level, some groups refused to work with the detention centre management, preferring to make contact with those in detention through protests and word of mouth. In so doing, visitors attempt to mitigate what Thomas Mathiesen calls structural silencing: the tendency to become silent about oppressive circumstance because of one's position in relation to authority (Mathiesen, 2005).

Secondly, in contrast to positioning oneself as host offering rigid and professionalised means of support, visiting attempts to establish relationships that are determined through the encounter, remaining flexible and responsive to the situation of those detained. As a trainer at a visitor-induction session put it, visitors are encouraged 'find a relationship that suit you as a pair', rather than focus on ways they can help based on preconceived ideas of what is needed. This included minor practices that attempted to respect the agency of the person being visited - making sure to call beforehand to arrange a visit, leaving at an agreed time, being led in conversation by topics that felt comfortable and not requesting details about histories that did not need to be shared.

This form of visiting means recognising the ability of those in detention to be hosts. Those visited assume hosting roles by offering gifts to visitors that are available in the room, such as water and vending machine chocolate (see: Rozakou, 2012). This was also evident in a group visit where those in detention tried to usurp the role of hosts from the detention centre staff and visitors by welcoming visitors in and trying to determine the acceptable forms of encounter allowed in the visiting room.

At the group visit to Yarl's Wood there were 7 visitors visiting 13 detained people (in two sessions of 2 hours each). On arrival to the visiting room each of us was welcomed with a hug at the door by one of the women who showed us to our places and offered us water. There was a feeling of occupying the space by challenging the restrictions on who one could talk to and what about. The staff engaged in a kind a game of cat and mouse trying to make sure that we each sat at the allocated tables and we could only talk to the person we had officially visited. At the change over some delayed leaving, making the room being packed with people. (author's field notes) 
Recognising the ability of the those in detention to host means visitors have to reduce the emphasis on the instrumentality of visiting. Visiting is less about offering prefigured rationales of support and aid and more about making connection and building relationships of mutual aid and friendships. This 'solidarity in the form of company' (Adam) involves being ready to encounter the ambiguity and discomfort about not knowing what to say and what one is trying to achieve.

The value of the visitor perspective is that it opens possibilities for the work of visitors to be led by those they are visiting. Hospitality, in Derrida's view, starts with rules and boundaries which are then overreached through supplementary decisions, in the name of unconditional hospitality. Visiting, in contrast, frequently adopts an open stance through which provisional roles and boundaries emerge and are negotiated. Georgia explains that boundaries involve:

Rules about how you form a relationship with someone... What is and isn't okay to communicate about, to ask of each other, limits to the amounts of contact. It's basically power, who has the power to define where that relationship can go.... Maybe that's one of the differences between visiting and providing a service is that in visiting you're trying to keep the question of power as a question. Whereas service providers have it written down on paper and signed on the dotted line that they're in control.

For Georgia, volunteering in its hosting dynamic can fix relationships as a one-sided offering of care and support where one's role is clearly demarcated. Whereas visiting is primarily about relationship building and a form of solidarity which starts from the needs and understanding of those one is visiting. This echoes US organiser Martin Lukacs' notion of solidarity in anti-oppression work that takes as a starting point the analysis of the people one wants to work with 'rather than imposing your own idea about how a struggle should proceed...solidarity at its most respectful and responsible is essentially a conversation' (Lukacs and Matchewen, 2012). This notion of antioppression work as a form of conversation is echoed by Ella, who states that:

First of all, [visiting is about] not assuming that I know how to enact my activism better than the people I'm working with. In visiting, you are allowing the people that you're doing that with to be guiding that relationship based on what they need or want. And then you making a decision about whether it's something you can do or you can't and having an honest conversation in which both of you are shaping it together. 
The third aspect draws on the connotation that one visits in order to move on: that the purpose of a visit is not necessarily in what is achieved while one visits but in the resources that are built through the process of visiting. In this view, visiting is a pedagogical and affective practice that supports learning about detention and builds capacities to resist detention. Rather than seeing the impact of visiting only as assisting individuals in detention - with its implications of paternalism, and saviourism (Spanierman and Smith, 2017: 609) - this view sees visiting as a mode of social movement building addressing detention as a systematic feature of racial governance.

Visiting, in other contexts, is already understood as 'a potential catalyst for social movement participation' (Mostafanezhad, 2014). Here, it serves as a pedagogical practice through which visitors learn about the UK's border infrastructure and enables reflection of the positionality of oneself in society. For example, Jane noted:

It's very rare that you're confronted with the realities of like state oppression basically. The physical signifiers are so strong and so marked. There are people locked in a building surrounded by barbed wire, you have to yourself go through security in order to see them, everyone who is being visited is a person of colour, everyone who is visiting is either white or family. ${ }^{8}$

For Jane, the physical experience of visiting was key not only to understanding the detention system as racist, state repression but also in understanding herself as privileged in relation to it. As well as encouraging individual reflection and participation in movement work, visiting is a means of building networks and relationships for strategizing and organising political interventions. Visitor relationships have been important to the organisation of anti-detention protests and projects that centre detainee voices in anti-detention campaigns. ${ }^{9}$ In this way, visiting attempts to counter the way detention works to break networks of care and resistance that those detained require for survival (Gill, 2009; Martin, 2015).

In summary, while detention volunteers adopt a familiar hosting model to understand their praxis, they have also crafted a visitor-model that they use to approach their work. This visiting-model prioritises remaining as an unsettled intervention into the detention centre. It aims to keep the visiting relationship open, mindful that prefigured

\footnotetext{
${ }^{8}$ While it was this visitor's experience that visitors were only white, this was not reflected in my interviews particularly in when working with one London based visiting group.

${ }^{9}$ One such project is the Detained Voices project (see detainedvoices.com).
} 
relations of support can ossify hierarchical relationships rather than work to foster more equal exchanges. The visiting mode also views visiting as part of the project of building solidarity networks and knowledge for further politicised involvement in anticarceral movements. It enables visitors to navigate their complicity with detention's hospitality by prioritising responsivity, intervention and transformation over being a fixed part of the detention landscape. In these ways, I argue that the visitor can be a subject of responsibility and hospitality, able to intervene in responsive ways to the needs and expectations of those they work with.

However, it is important to be mindful of the limitations of this approach. The emphasis on open-endedness and lack of pre-defined purpose can leave visitors unsure what their role should be, generating anxiety as to their usefulness and impact. It can also be unclear and confusing for those visited. While the more open-ended nature of visiting attempts to overcome the tendency of visitors to direct the relationship, the intervention is unstable, difficult to sustain over the longer term ${ }^{10}$ and perhaps means that visitors are more susceptible to forms of vicarious or 'contagious' trauma (Coddington, 2017). One visitor-coordinator, Robin, was conscious of this in the visiting work they supported. They disclosed that:

We are bad at encouraging conversations about boundaries and expectations... We don't support individuals to have conversations about it. Having these conversations might reduce anxiety, and make everybody feel more comfortable. It's quite fictitious to think that friendships can be made from a clean slate in such an artificial environment.

Robin, here, is anxious to do more to support visitors in having explicit conversations about boundaries with those they are visiting. In doing so they challenge the idea that visiting relationships should be left to figure out their dynamics on their own. They also encourage visitors, as a collective, to be more reflective about the environment in which visiting relationships are formed and to attend to the fact that even the most open and politically engaged approaches to visiting are shaped by, and reliant upon, the coercive boundaries placed on those incarcerated by the detention centre.

\footnotetext{
${ }^{10}$ Georgia, for example, told me that 'I did it for so long that I started to put it in a service provision box. I did it for so much longer than I should of done.'
} 


\section{Conclusion}

In this article, I have argued that a critical approach to hospitality illuminates both the complicity of charitable actors in detention and suggests opportunities for subversive practice. Firstly, hospitality studies draw attention to the ways in which detention visiting groups perform their work as hosts: as permanent fixtures in detention, in control of the affective and strategic resources on offer to the guest. These resources are organised to fulfil strategic objectives (individual survival and getting individuals out of detention). Yet the primacy of these instrumental logics can produce unequal distributions of power and unidirectional relationships that conflict with the egalitarian aims of detention visiting. It introduces closures upon the practice of visiting limiting the opportunities for politicisation and reinforces dominant mythologies of migrants as unembedded and mobile guests. A critical hospitality approach, also, illuminates the ways visitors participate in detention in ways that make the hostile and exclusionary processes more manageable and easier to operate.

Secondly, I have identified a subversive and prefigurative thread of volunteer visiting in the ways it attempts to reverse the assumed relationship between host-citizen and guest-migrant. This approach places emphasis on establishing collaborative, and mutually beneficial relationships between people subject to border control and the people supporting them. Visiting outlines a way of performing solidarity from a position of relative unknowing about the experience of border violence. These relationships are founded through a focus on the ways they are reflexive and flexible rather than service-oriented, solidaristic rather than instrumental and connected to other forms of political action. In doing so, detention visitors are crafting novel and potentially fruitful conceptual resources to apply elsewhere, in spaces where questions about the politics and cultures of welcome arise and in organisations that attempt to intervene in institutions of state violence that are interwoven with logics of care.

Recognising the coexistence of these divergent roles is important in developing radical visiting praxes in which visitors shift between contradictory roles. Visitors do this because the urgent conditions mean that a singular consistent approach cannot be maintained. Visiting therefore reflects what Karma Chávez (2014), drawing on Sandoval (2000), calls 'differential strategy'. This concept describes social movement approaches that enable flexibility between different activist stances in order to enable coalitions to emerge and actions to be carried out that facilitate emancipatory or progressive ends. Furthermore, understanding the complex interplay between the 
roles adopted by detention volunteers also allows for an analysis which attends to the diversity of approaches to anti-detention activism. And therefore aids analyses that recognises that complicity and co-option exist but do not over-determine and eliminate the agency of volunteers and those incarcerated to generate political relationships within carceral spaces (Tomczak, 2014).

This discussion of detention visiting also develops our understanding of hospitality and its usefulness in approaching the carceral institutions of border enforcement. For those critical of the border regime, the uncritical deployment of a politics of hospitality risks participating in problematic demarcations of belonging and mobility, reinforces the power of the host to effect social control over the guest and glosses over how hospitality to one group of deserving guests is connected to the hostility dealt out to the undeserving or illegal guests (Fassin, 2012: 136). It also shows how it is important to develop the Derridean notions of hospitality in order to make fully make use of critical hospitality studies. Both Derrida and his critics have tended to view hosting as the primary mode of offering hospitality and tended to look for hospitality politics in spaces where there are clearly delineated hosts and guests. This framing obscures spaces, such as detention centre visiting, in which the practice of hospitality constructs hosts and guests in messier and more enmeshed ways than it would first seem. This form of detention activism prompts a conceptual shift from thinking about hosting towards visiting, in which the subject of 'visitor' appears as a possibly helpful metaphorical tool to engage in activist ethics and allyship.

\section{Bibliography}

Aas KF and Bosworth M (eds) (2013) The Borders of Punishment: Migration, Citizenship, and Social Exclusion. First edition. Oxford, United Kingdom: Oxford University Press.

Andersson R (2014) Illegality, Inc.: Clandestine Migration and the Business of Bordering Europe. 1 edition. Oakland, CA: University of California Press.

Baker G (2010) The 'Double Law' of Hospitality: Rethinking Cosmopolitan Ethics in Humanitarian Intervention. International Relations 24(1): 87-103.

Bales WD and Mears DP (2008) Inmate Social Ties and the Transition to Society: Does Visitation Reduce Recidivism? Journal of Research in Crime and Delinquency. 
Barnett C (2005) Ways of relating: hospitality and the acknowledgement of otherness. Progress in Human Geography 29(1): 5-21.

Benveniste É and Lallot J (1973) Indo-European Language and Society. University of Miami Press.

Bosworth M (2012) Subjectivity and identity in detention: Punishment and society in a global age. Theoretical Criminology 16(2): 123-140.

Bosworth M (2013) Can Immigration Detention Centres be Legitimate? In: Aas KF and Bosworth M (eds) The Borders of Punishment: Migration, Citizenship, and Social Exclusion. First edition. Oxford, United Kingdom: Oxford University Press.

Bosworth M (2014) Inside Immigration Detention. Oxford, United Kingdom: Oxford University Press.

Bowling B and Westenra S (2018) 'A really hostile environment': Adiaphorization, global policing and the crimmigration control system. Theoretical Criminology: $1-21$.

Brown GW (2010) The Laws of Hospitality, Asylum Seekers and Cosmopolitan Right A Kantian Response to Jacques Derrida. European Journal of Political Theory 9(3): 308-327.

Bulley D (2015) Ethics, power and space: International hospitality beyond Derrida. Hospitality \& Society 5(2): 185-201.

Candea M (2012) Derrida en Corse? Hospitality as scale-free abstraction. Journal of the Royal Anthropological Institute 18: S34-S48.

Candea M and Da Col G (2012) The return to hospitality. Journal of the Royal Anthropological Institute 18: S1-S19.

Carlson D (2009) The Border Crossed Us: Education, Hospitality Politics, and the Social Construction of the "Illegal Immigrant". Educational Theory 59(3): 259-277.

Chavez KR (2014) Queer Migration Politics: Activist Rhetoric and Coalitional Possibilities. Urbana: University of Illinois Press. 
Cochran JC (2012) The ties that bind or the ties that break: Examining the relationship between visitation and prisoner misconduct. Journal of Criminal Justice 40(5). The Prison Experience: 433-440.

Cochran JC and Mears DP (2013) Social isolation and inmate behavior: A conceptual framework for theorizing prison visitation and guiding and assessing research. Journal of Criminal Justice 41(4): 252-261.

Coddington K (2017) Contagious trauma: Reframing the spatial mobility of trauma within advocacy work. Emotion, Space and Society 24. On trauma, geography, and mobility: Towards geographies of trauma: 66-73.

Coutin SB (2005) Contesting criminality: Illegal immigration and the spatialization of legality. Theoretical Criminology 9(1): 5-33.

Darling J (2009) Becoming Bare Life: Asylum, Hospitality, and the Politics of Encampment. Environment and Planning D: Society and Space 27(4): 649-665.

Darling J (2010) A city of sanctuary: the relational re-imagining of Sheffield's asylum politics. Transactions of the Institute of British Geographers 35(1): 125-140.

Darling J (2014) From Hospitality to Presence. Peace Review 26(2): 162-169.

Derrida J (1989) The Force of Law: The mystical foundation of authority. Cardozo L. Rev. 11: 920-1045.

Derrida J (1997) Adieu à Emmanuel Lévinas. Incises. Paris: Galilée.

Derrida J (2001) On Cosmopolitanism and Forgiveness. London; New York: Routledge.

Derrida J (2005) The Principle of Hospitality. Parallax 11(1): 6-9.

Derrida J and Anidjar G (2002) Acts of Religion. New York: Routledge.

Derrida Jacques and Dufourmantelle Anne (2000) Of Hospitality. Stanford, Calif.: Stanford University Press.

Dikeç M (2002) Pera Peras Poros Longings for Spaces of Hospitality. Theory, Culture \& Society 19(1-2): 227-247. 
Duwe G and Clark V (2013) Blessed Be the Social Tie That Binds The Effects of Prison Visitation on Offender Recidivism. Criminal Justice Policy Review 24(3): 271296.

Fadaee $S$ (2015) The Immigrant Rights Struggle, and the Paradoxes of Radical Activism in Europe. Social Movement Studies 14(6): 733-739.

Fassin D (2007) Humanitarianism as a Politics of Life. Public Culture 19(3): 499-520.

Fassin D (2012) Humanitarian Reason: A Moral History of the Present Times. Berkeley: University of California Press.

Friese H (2010) The Limits of Hospitality: Political Philosophy, Undocumented Migration and the Local Arena. European Journal of Social Theory 13(3): 323341.

Gardey D (2016) "Territory Trouble": Feminist Studies and (the Question Of) Hospitality. differences 27(2): 125-152.

Gibson S (2006) Border Politics and Hospitable Spaces in Stephen Frears's Dirty Pretty Things. Third Text 20(6): 693-701.

Gill N (2009) Longing for Stillness: The Forced Movement of Asylum Seekers. M/C Journal 12(1).

Gill N (2016) Nothing Personal?: Geographies of Governing and Activism in the British Asylum System. John Wiley \& Sons, Ltd.

Hamington M (2010) Toward a Theory of Feminist Hospitality. Feminist Formations 22(1): 21-38.

Humbracht M (2015) Reimagining Transnational Relations: the Embodied Politics of Visiting Friends and Relatives Mobilities. Population, Space and Place 21(7): 640-653.

Kanstroom D (2007) Deportation Nation: Outsiders in American History. Harvard University Press.

Kant I (1795) Perpetual Peace: A Philosophical Sketch. 
Lamble S (2013) Queer Necropolitics and the Expanding Carceral State: Interrogating Sexual Investments in Punishment. Law and Critique 24(3): 229-253.

Lukacs M and Matchewen N (2012) Widj-e-nia-mo-dwin: Walking together for Indigenous rights.

Lynch P, Molz JG, Mcintosh A, et al. (2011) Theorizing hospitality. Hospitality \& Society 1(1): 3-24.

Maeckelbergh M (2011) Doing is Believing: Prefiguration as Strategic Practice in the Alterglobalization Movement. Social Movement Studies 10(1): 1-20.

Martin L (2015) Noncitizen Detention: Spatial Strategies of Migrant Precarity in US Immigration and Border Control. Annales de geographie $\mathrm{n}^{\circ}$ 702-703(2): 231247.

Mathiesen T (2005) Silently Silenced: Essays on the Creation of Acquiescence in Modern Society. Winchester: Waterside Press.

Mezzadra S (2004) The Right to Escape. Ephemera: Theory and Politics in Organization 4(3): 267-275.

Millner N (2011) From "refugee" to "migrant" in Calais solidarity activism: Re-staging undocumented migration for a future politics of asylum. Political Geography 30(6): 320-328.

Moran D (2013) Carceral Geography and the Spatialities of Prison Visiting: Visitation, Recidivism, and Hyperincarceration. Environment and Planning D: Society and Space 31(1): 174-190.

Moran DD (2015) Carceral Geography: Spaces and Practices of Incarceration. Ashgate Publishing, Ltd.

Mostafanezhad M (2014) Volunteer Tourism: Popular Humanitarianism in Neoliberal Times. New directions in tourism analysis. Farnham, Surrey, England ; Burlington, VT: Ashgate Publishing Company.

Pakes FJ and Holt K (2016) Crimmigration and the prison:comparing trends in prison policy and practice in England and Wales, and Norway. European Journal of Criminology. 
Reisinger $Y$ and Steiner C (2006) Reconceptualising Interpretation: The Role of Tour Guides in Authentic Tourism. Current Issues in Tourism 9(6): 481-498.

Reynolds J (2002) Habituality and Undecidability: A Comparison of Merleau-Ponty and Derrida on the Decision. International Journal of Philosophical Studies 10(4): 449-466.

Rocha Gómez JL (2014) Hospitality as Civil Disobedience. Peace Review 26(2): 185-191.

Rosello M (2001) Postcolonial Hospitality: The Immigrant as Guest. Stanford University Press.

Rowlands A (2018) Against the Manichees: Immigration Detention and the Shaping of the Theo-political Imagination. In: Schmiedel U and Smith G (eds) Religion in the European Refugee Crisis. Religion and Global Migrations. Cham: Springer International Publishing, pp. 163-186.

Rozakou K (2012) The biopolitics of hospitality in Greece: Humanitarianism and the management of refugees. American Ethnologist 39(3): 562-577.

Sandoval C (2000) Methodology of the Oppressed. Theory out of bounds v. 18. Minneapolis, MN: University of Minnesota Press.

Scott D (2009) Resistance as reform: direct action through prisoner movements, legal activism and the radical penal lobby. Criminal Justice Matters 77(1): 20-21.

Silverman SJ and Massa E (2012) Why Immigration Detention is Unique. Population, Space and Place 18(6): 677-686.

Spanierman LB and Smith L (2017) Roles and Responsibilities of White Allies: Implications for Research, Teaching, and Practice. The Counseling Psychologist 45(5): 606-617.

Still J (2010) Derrida and Hospitality: Theory and Practice. Edinburgh: Edinburgh University Press.

Stronks MC (2012) The question of Salah Sheekh: Derrida's hospitality and migration law. International Journal of Law in Context 8(01): 73-95. 
Stumpf JP (2006) The crimmigration crisis: Immigrants, crime, and sovereign power. American University Law Review 56: 367.

Tomczak PJ (2014) The penal voluntary sector in England and Wales: Beyond neoliberalism? Criminology \& Criminal Justice 14(4): 470-486.

Turnbull S (2017) Immigration Detention and the Racialized Governance of Illegality in the United Kingdom. Social Justice; San Francisco 44(1): 142-164.

Tyler I, Gill N, Conlon D, et al. (2014) The business of child detention: charitable cooption, migrant advocacy and activist outrage. Race \& Class 56(1): 3-21.

Westmoreland MW (2008) Interruptions: Derrida and hospitality. Kritike 2(1): 1-10. 